\title{
Modeling Actual Evapotranspiration using the Advection Aridity Model
}

\author{
Ananya S.G, Lakshman Nandagiri
}

\begin{abstract}
Evapotranspiration is a major process in the hydrological cycle. Between 40 to $60 \%$ of precipitation is returned back to the atmosphere in the form of evapotranspiration. Therefore, estimation of Actual Evapotranspiration (AET) is important in studies related to hydrology, agriculture and climate. However, due to the fact that calculation of AET using conventional methods require data pertaining to climate, vegetation/crop and soil moisture levels, estimation of spatial AET becomes a very tedious task. The Complementary Relationship Areal Evapotranspiration (CRAE) hypothesis has been proposed as a simpler alternative to estimate AET from large spatial domains using only routinely observed meteorological data thereby circumventing the need for data on soil-vegetation. The objective of the present work was to apply the CRAE hypothesis in Karnataka State, India and evaluate the accuracy of estimates using MODIS satellite-derived AET estimates.

The Advection Aridity (AA) model which is based on the CRAE hypothesis was chosen to estimate AET using historical climate records of the Afzalpur and Hungund stations. The AA model uses the Penman equation to estimate the Potential ET and the Priestley-Taylor equation to estimate Wet Environment ET which are needed to estimate AET. Accuracy of AET values obtained from the AA model were validated using the MODIS MOD16A2 evapotranspiration product, which provides an 8-day composite AET estimate at $500 \mathrm{~m}$ resolution. AET estimated by the $A A$ model compared favorably with MOD16A2 with the average Coefficient of determination (R2)for the two stations being 0.8095 .

While the results of this study have shown that the AA model provides reasonably accurate AET estimates with minimum data, further studies need to be carried out to improve the accuracy through local calibration of parameters.
\end{abstract}

Keywords: Actual Evapotranspiration; Advection-Aridity Model; Complementary Relationship; Potential Evapo-transpiration; Wet-environment Evapotranspiration..

\section{INTRODUCTION}

Evapotranspiration (ET) represents the combined processes of evaporation of moisture from bare soil surfaces, evaporation of rainfall intercepted by vegetation surfaces, evaporation from open water bodies and transpiration from vegetation. From a hydrological viewpoint it is considered as a major loss since at a given location, $40-60 \%$ of incident annual rainfall is returned back to the atmosphere by the process of ET. ET is a complex phenomenon which is influenced by a large number of variables related to climate,

soil and vegetation and constitutes an important feedback mechanism between land surface and atmospheric processes. ET exhibits significant temporal and spatial variabilities on account of seasonal changes in climatic conditions and heterogeneity in soils and vegetation. Accurate estimation of ET rates and characterization of the spatiotemporal variability of ET is essential in studies related to hydrology, water resources, agriculture and climate.

An extensive body of literature exists on previous studies carried out to characterize ET from heterogeneous landscapes in different climatic regimes of the world. Results from such world-wide research studies have culminated in the formulation of a standardized procedure for computing ET using data pertaining to climate, soil and vegetation. The fundamental premise of this conventional approach is that the actual evapotranspiration rate (ETa) under given climatic conditions from a given vegetative cover under existing levels of soil moisture is a function of potential or reference crop evapotranspiration (ETp) which is determined solely from prevailing climatic conditions. Therefore, once ETp is determined from climate records, it is subsequently converted to ETa by accounting for the vegetation characteristics and soil moisture availability. The best example of the manner in which this procedure may be implemented to compute ET rates of agricultural crops in contained in the report of the United Nations Food and Agricultural Organization (UN-FAO) (Allen et al., 1998) [1]. Despite the wide spread popularity of the FAO procedure amongst both researchers and practitioners across the globe, this approach possesses the following inadequacies when applied to catchment-scale hydrological studies: 1) intensive requirement of input data relating to climate, vegetation and soils 2) difficulty in upscaling point-values to heterogeneous catchment/regional scales 3) focus on agricultural crops and lack of documented information on characteristics of natural vegetation. Therefore, any ET estimation method which circumvents the above inadequacies should prove to be extremely useful in catchment/regional-scale hydrological studies and water resources assessments.

Bouchet in 1963 [2] proposed that at regional scales, there exists a complementary relationship between ETp and ETa and argued that rather than ETa being a function of ETp, the converse is true. Accordingly, he proposed an approach for estimating regional ETa rates directly from measured 
climatic records thereby circumventing the need for complex data on the soil-vegetation system. Subsequently, a large number of studies have evaluated Bouchet's hypothesis and proved the existence of the complementary relationship in different climatic regimes and also refined the original approach for estimating regional ET. For instance, Morton [3] provided a theoretical framework called Complementary Relationship Areal Evapotranspiration (CRAE) and developed an operational procedure for computing regional ET from routinely recorded climate data. Brutsaert and Stricker[4] put forward the Advection-Aridity model (AA model) based on Bouchet's Complementary relationship hypothesis(CR hypothesis). They applied the AA model in a rural catchment in Hupsel creek in the Eastern part of the Netherlands and found that the model provided reliable estimates of ETa. Many other studies have proved the reliabilzity of the $\mathrm{CR}$ hypothesis by validating the ET estimates with those obtained by other methods like pan evaporation, water balance method[5][6][3] and lysimeters[7][8]. Some studies compared different versions of the Complementary Relationship [9][10][11][12][14]. However, few studies seem to have been taken up to apply the CRAE approach in India to derive regional ET estimates. Therefore, the present study was taken up with the objective of estimating ET across Karnataka State, India using the CRAE approach. Owing to its simplicity and proven accuracy, the Advection-Aridity model was selected for implementation in the study. The goals of the present work are (1) to apply the AA model to estimate ETa across Karnataka using historical records from climate stations and (2) to evaluate the accuracy of the ETa estimates using MODIS satellite-derived estimates

\section{METHODOLOGY}

\section{A. Complementary Relationship Hypothesis}

The CRAE hypothesis states that over a large area away from sharp environmental discontinuities there exists a complementary relationship between ETp and ETa. If soil moisture is not restricted and the sole limiting factor is energy, then ETp and ETa are equal and that ET is known as wet environment ET (ETw). When the moisture content falls, the difference in energy (q) becomes available for sensible heat flux that heats the environment which in turn increases the ETp and decreases ETa by the same amount (q). Accordingly, as per CRAE,

$$
\mathbf{E T w}=\mathbf{E T p}-\mathbf{q}
$$$$
\mathbf{E T w}=\mathbf{E T a}+\mathbf{q}
$$

Adding Equations 1 and 2, we get,

$\mathbf{2 E T w}=\mathbf{E T p}+\mathbf{E T a}$

Equation 2.3 may be recast to get ETa as,

$\mathrm{ETa}=2 \mathrm{ETw}-\mathrm{ETp}$

Fig 1 provides a conceptual representation of the CRAE as defined by Equation 4 .

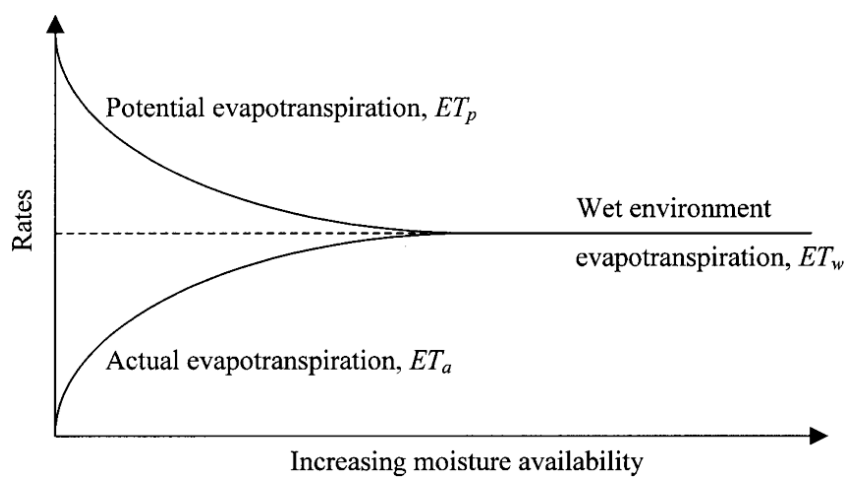

Fig 1 : Conceptual representation of the Complementary Relationship

\section{B. Advection-Aridity Model}

Based on the concept proposed by Bouchet(1963)[2], Brutsaert and Stricker (1979)[4] developed the Advection-Aridity (AA) model. According to their approach, in Equation 2.4, ETw was estimated by Priestley Taylor (1972)[13] equation and ETp was estimated by the FAO-24 Penman method. In the present study, the more physically-based FAO-56 Penman Monteith method proposed by Allen et al. (1998)[1] was used to estimate ETp. In the following sections, the set of algorithms to calculate ETw using the Priestley- Taylor method (1972)[13] and ETp using the Penman-Monteith method are explained in detail.

\section{Priestley Taylor Equation}

Priestley Taylor equation is given as below

$$
E T w=\alpha * \frac{\Delta}{\Delta+\gamma} * Q n
$$

Where $\gamma$ is psychrometric constant, $\Delta$ is slope of the saturation vapor pressure curve at actual air temperature, $\alpha$ is Priestley Taylor parameter which typically varies in the range 1.1 to 1.4 and $\mathrm{Qn}$ is energy available computed using Equation (6).

$$
Q_{n}=R_{n}-G
$$

Where $\mathrm{Rn}$ is net radiation and $\mathrm{G}$ is ground heat flux. Net radiation is computed as,

$$
R_{n}=R_{n s}-R_{n l}
$$

Where Rns is the incoming net shortwave radiations and $\mathrm{Rnl}$ is the outgoing net long wave radiation. The net shortwave radiation (Rns) is obtained from the balance between incoming and reflected radiation from the sun. That is,

$$
R_{n s}=(1-\alpha) * R_{s}
$$

Where $\alpha$ is albedo or canopy reflection coefficient, which is equal to 0.23 for the hypothetical grass reference crop and $\mathrm{Rs}$ is the incoming radiation from the sun in $\mathrm{MJ} \mathrm{m}^{-2}$ day ${ }^{-1}$.

The earth, which has significantly lesser temperature than the sun, emits radiative energy with wavelengths longer than those from the sun. Therefore, the terrestrial radiation is referred to as long wave radiation. Net long wave radiation 
$(\mathrm{Rnl})$ is given by,

$$
\underset{\mathbf{0 . 3 5}}{\mathbf{R}_{\mathbf{n l}}=\boldsymbol{\sigma} *\left[\frac{\mathrm{T}_{\mathrm{max}, \mathrm{K}}^{4}+\mathbf{T}_{\min , \mathrm{K}}^{4}}{2}\right] *\left(0.34-0.14 \sqrt{\mathbf{e}_{\mathbf{a}}}\right) *\left(1.35 * \frac{\mathbf{R}_{\mathbf{s}}}{\mathbf{R}_{\mathbf{s o}}}-\right.}
$$

Where $\sigma$ is Stefan-Boltzmann constant whose value is 4.903 10-9 $\mathrm{MJ} \mathrm{K}^{-4} \mathrm{~m}^{-2}$ day $^{-1}$.TmaxK, and TminK are maximum and minimum absolute temperature during the 24-hour period in Kelvin units, ea is actual vapor pressure in $\mathrm{kPa}$, Rs is measured or calculated solar radiation in $\mathrm{MJ} \mathrm{m}^{-2}$ day $^{-1}$ that reaches the surface of the earth in a given period and is given by

$$
\mathbf{R}_{\mathbf{s}}=\left(\mathbf{a}_{\mathbf{s}}+\mathbf{b}_{\mathbf{s}} * \frac{\mathbf{n}}{\mathbf{N}}\right) * \mathbf{R}_{\mathbf{a}}
$$

Where $\mathrm{n}$ is the actual duration of daylight in hours, $\mathrm{N}$ is the maximum possible duration of daylight hours.

Rso is the radiation from the sun that would reach the same surface during the same period but under clear sky conditions $\left(\mathrm{MJ} \mathrm{m}^{-2}\right.$ day $\left.^{-1}\right)$. The clear sky radiation is as given by,

$$
\mathbf{R}_{\text {so }}=\left(\mathbf{0 . 7 5}+\mathbf{2} * \mathbf{1 0}^{-\mathbf{5}} * \mathbf{z}\right) * \mathbf{R}_{\mathbf{a}}
$$

The radiation from the sun received at the top of the atmosphere of the earth on a horizontal surface is called the extraterrestrial solar radiation $(\mathrm{Ra})\left(\mathrm{MJ} \mathrm{m}^{-2} \mathrm{day}^{-1}\right)$, which is calculated using,

$$
\begin{array}{rl}
\mathbf{R a}=\frac{24 * 60}{\Pi} * \mathbf{G}_{\mathbf{s c}} & * \mathrm{dr} \\
& *\left[\omega_{\mathrm{s}} * \sin (\varphi) * \sin (\delta)+\cos (\varphi) * \cos (\delta)\right. \\
& \left.* \sin \left(\omega_{\mathrm{s}}\right)\right]
\end{array}
$$

Where as is regression constant, which expresses the fraction of extraterrestrial radiation reaching the earth on overcast days $(n=0)$ whereas as $+b s$ is fraction of extraterrestrial radiation reaching the earth on clear days $(\mathrm{n}=$ $\mathrm{N}), \mathrm{z}$ is the station elevation above sea level in meters, Gsc is a solar constant whose value is equal to $0.0820 \mathrm{MJm}^{-2} \mathrm{~min}^{-1}$. The inverse relative distance earth-sun (dr) as given by,

$$
d_{r}=1+0.33 \cos \left(\frac{2 \pi}{365} J\right)
$$

The number of the day in the year between 1 and365/366 is denoted by $\mathbf{J}$.

The solar declination $(\delta)$ which is calculated using,

$$
\delta=0.409 \sin \left(\frac{2 \pi}{365} \mathrm{~J}-1.39\right)
$$

The sunset hour angle ( $\omega s)$ is calculated using,

$$
\omega_{\mathrm{s}}=\arccos [-\tan (\varphi) \tan (\delta)]
$$

Where $\varphi$ is latitude of the station.

$\mathrm{N}$ represents the daylight hours which is the utmost possible duration of sunshine in a day and obtained through the following equation.

$$
\mathbf{N}=\frac{\mathbf{2 4}}{\boldsymbol{\pi}} \boldsymbol{\omega}_{\mathrm{s}}
$$

The soil heat flux $(\mathrm{G})$ is computed using,

$$
\mathbf{G}_{\text {month,i }}=\mathbf{0 . 1 4} *\left(\mathbf{T}_{\text {month, } \mathbf{i}}-\mathbf{T}_{\text {month,i-1 }}\right)
$$

Where $\mathrm{T}_{\text {month,i }}$ is the monthly average temperature of the month to which we are calculating the soil heat flux, while $\mathrm{T}_{\text {month,i-1 }}$ is the monthly average temperature of the preceding month.

\section{Penman-Monteith Equation}

Potential ET is estimated by the equation of Penman-Monteith as

$$
\mathbf{E T}_{\mathbf{p}}=\frac{0.408 * \Delta *\left(\mathbf{R}_{\mathbf{n}}-\mathbf{G}\right)+\gamma * \frac{900}{\mathbf{T}+273} * \mathbf{u}_{2} *\left(\mathbf{e}_{\mathbf{s}}-\mathbf{e}_{\mathbf{a}}\right)}{\Delta+\gamma\left(1+0.34 \mathbf{u}_{2}\right)}
$$

Where ETp is potential evapotranspiration in mm day -1 , $\mathrm{Rn}$ is net radiation at the crop surface in $\mathrm{MJ} \mathrm{m}^{-2}$ day $^{-1}, \mathrm{G}$ is ground heat flux density in $\mathrm{MJ} \mathrm{m}^{-2}$ day $^{-1}, \mathrm{~T}$ is air temperature at $2 \mathrm{~m}$ height in degree Celsius, $\mathrm{u} 2$ is wind velocity at $2 \mathrm{~m}$ height with the unit $\mathrm{ms}^{-1}$, es and ea are saturation and actual vapor pressure measured in $\mathrm{kPa}, \Delta$ is a slope vapor pressure curve in $\mathrm{kPa}^{\circ} \mathrm{C}^{-1}$ and $\gamma$ is psychrometric constant in $\mathrm{kPa}^{\circ} \mathrm{C}^{-1}$.

\section{E. Study Area and Application}

The two stations chosen for study are Afzalpur $\left(17.2^{\circ} \mathrm{N}\right.$ $\left.76.35^{\circ} \mathrm{E}\right)$ and Hungund $\left(16.07^{\circ} \mathrm{N} 76.05^{\circ} \mathrm{E}\right)$ which are located in the Northern part of Karnataka State, India. These stations experience semi-arid climate. In the recent years, due to inadequate rainfall and depleting water table, the water shortage has intensified in these regions and crops growing in this region face water scarcity. Therefore the calculation of ET becomes very vital in these regions, and thus they are selected for the study.

Using the climate data procured from the State Water Resources Development Organization for eleven years (2006 to 2016), monthly estimates of ETa were obtained for both the climate stations for the period of record using the AA methodology described earlier. Distribution of the climatic parameters used for the calculations are shown in the box and whisker diagram in Fig 2 and Fig 3 for Afzalpur and Hungund stations respetively.

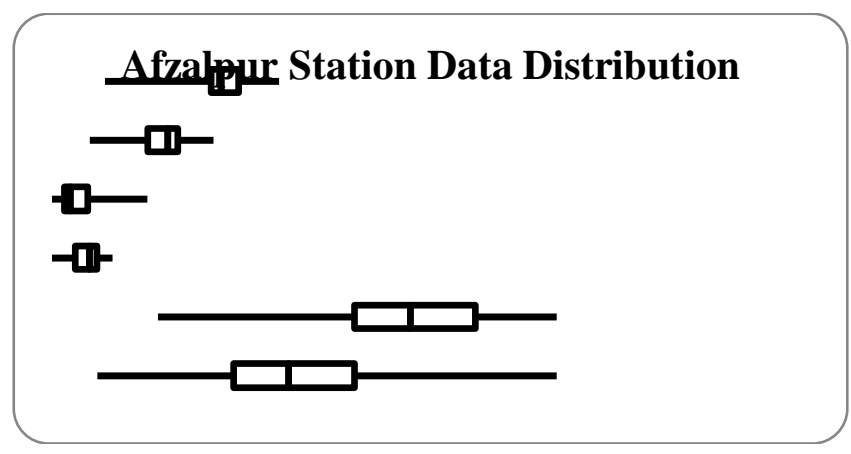

Fig 2: Box and Whisker diagram showing the Data distribution for the Afzalpur Station

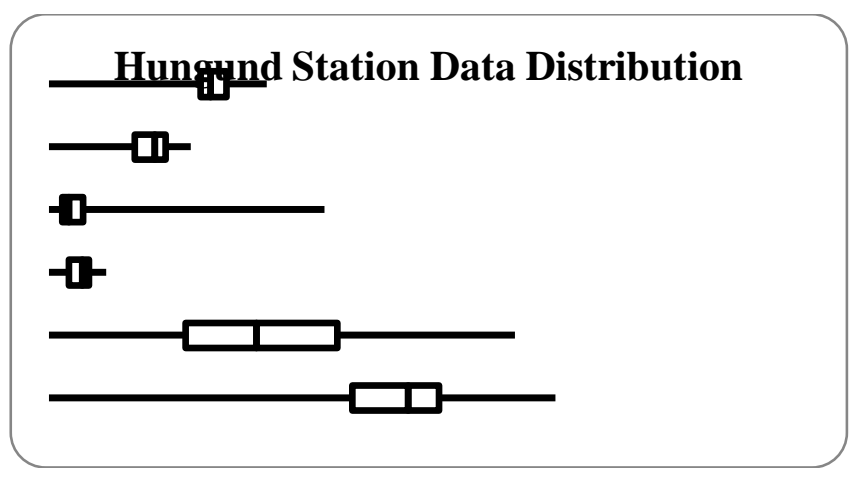

Fig 3: Box and Whisker diagram showing the Data distribution for the Hungund Station 


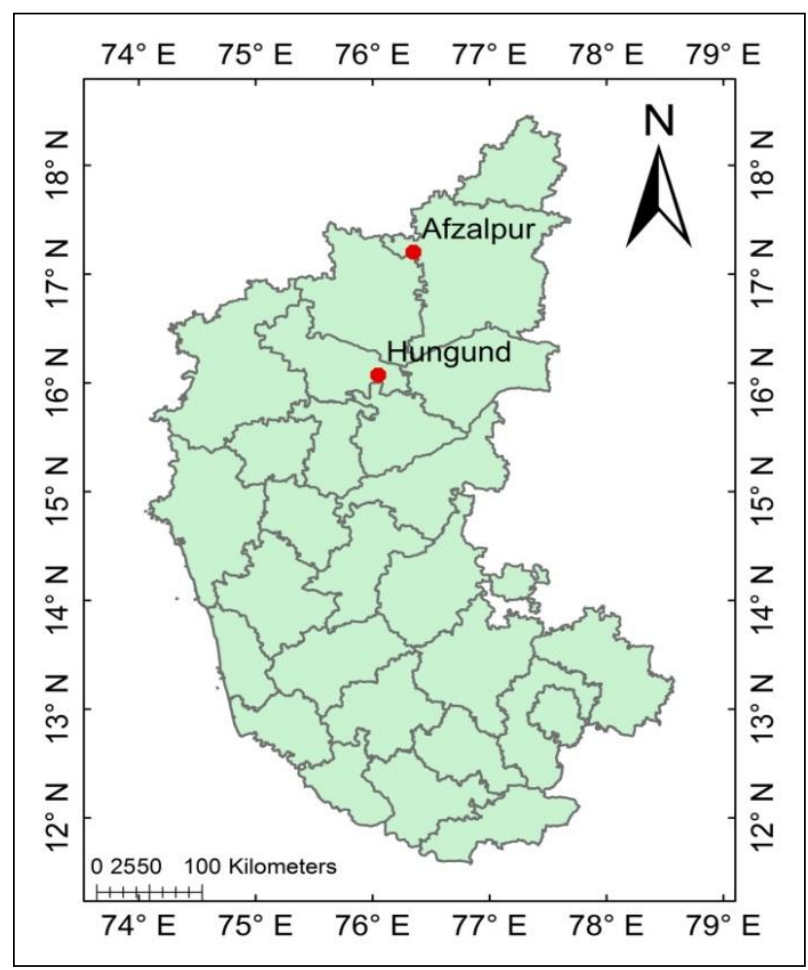

Fig 4: Location Map of climate Stations

Further, the accuracy of ETa values obtained by the AA model were evaluated using ETa values available in the satellite-based Moderate Resolution Imaging Spectroradiometer (MODIS) data product MOD16 ET.

\section{RESULTS AND DISCUSSION}

\section{F. Application of the AA model}

The monthly ETa values for the two stations were calculated using the algorithm described earlier using monthly mean climate data of minimum temperature, maximum temperature, minimum humidity, maximum humidity, wind speed and sunshine hours for eleven years (2006 to 2016). MATLAB® software was used to implement the algorithm. Computed monthly values of ETp, ETw and ETa averaged of the 11 year period are presented in Table 1.

Calculations showed that the average annual value of ETp and ETa were $5.92 \mathrm{~mm} \mathrm{~d}^{-1}$ and $2.18 \mathrm{~mm} \mathrm{~d}^{-1}$ respectively for Hungund station. At the Afzalpur station annual average potential and actual ET were $5.96 \mathrm{mmd}^{-1}$ and $2.60 \mathrm{~mm} \mathrm{~d}^{-1}$ respectively.

Mean monthly values of ETp, ETw, and ETa are plotted in Fig 5for the Afzalpur station and Fig 6 for the Hungund station. From these graphsit can be noticed that ETp values are in higher range during summer for both the stations and reach the peak in the month of May. Due to the limited moisture availability in the summer, ETa decreases significantly. As the rainy season approaches, there is a decrease in ETp along with increase in ETa and they both tend to become equal to ETw during the rainy season when there is abundant moisture in the soil. These results conform to the CRAE hypothesis.

\section{G. Verification of the CRAE hypothesis}

Although the relative magnitudes of ETp and ETa presented earlier provide proof for the CRAE hypothesis, this issue was further investigated. Accordingly, graphical plots were drawn showing the variation of standardized values of monthly average ET values with the standardized values of monthly average rainfall.

Table I: Mean monthly values of computed ETp, ETw, ETa values for the two climate station

\begin{tabular}{|c|c|c|c|c|c|c|}
\hline Station & \multicolumn{3}{|c|}{ Hungund } & \multicolumn{3}{c|}{ Afzalpur } \\
\hline Month & $\begin{array}{c}\text { ETP } \\
(\mathrm{mm})\end{array}$ & $\begin{array}{c}\text { ETW } \\
(\mathrm{mm})\end{array}$ & $\begin{array}{c}\text { ETA } \\
\text { mm })\end{array}$ & $\begin{array}{c}\text { ETP } \\
(\mathrm{mm})\end{array}$ & $\begin{array}{c}\text { ETW } \\
(\mathrm{mm})\end{array}$ & $\begin{array}{c}\text { ETA } \\
(\mathrm{mm})\end{array}$ \\
\hline January & 5.3 & 4.53 & 3.76 & 4.25 & 3.22 & 2.2 \\
\hline February & 6.11 & 3.78 & 1.44 & 5.75 & 4 & 2.25 \\
\hline March & 7.14 & 4.19 & 1.25 & 7.06 & 4.55 & 2.04 \\
\hline April & 8.57 & 4.83 & 1.09 & 8.47 & 5.17 & 1.87 \\
\hline May & 9.28 & 5.03 & 0.77 & 10.18 & 5.72 & 1.26 \\
\hline June & 6.46 & 4.33 & 2.2 & 7.53 & 4.87 & 2.22 \\
\hline July & 5.47 & 3.77 & 2.08 & 5.91 & 3.96 & 2.01 \\
\hline August & 5.42 & 4.1 & 2.77 & 5.27 & 4.31 & 3.35 \\
\hline September & 4.88 & 4.09 & 3.29 & 4.44 & 4.31 & 4.18 \\
\hline October & 4.65 & 4.09 & 3.53 & 4.55 & 4.37 & 4.19 \\
\hline November & 4.01 & 3.34 & 2.67 & 4.21 & 3.73 & 3.29 \\
\hline December & 3.76 & 2.58 & 1.4 & 3.93 & 3.15 & 2.35 \\
\hline
\end{tabular}

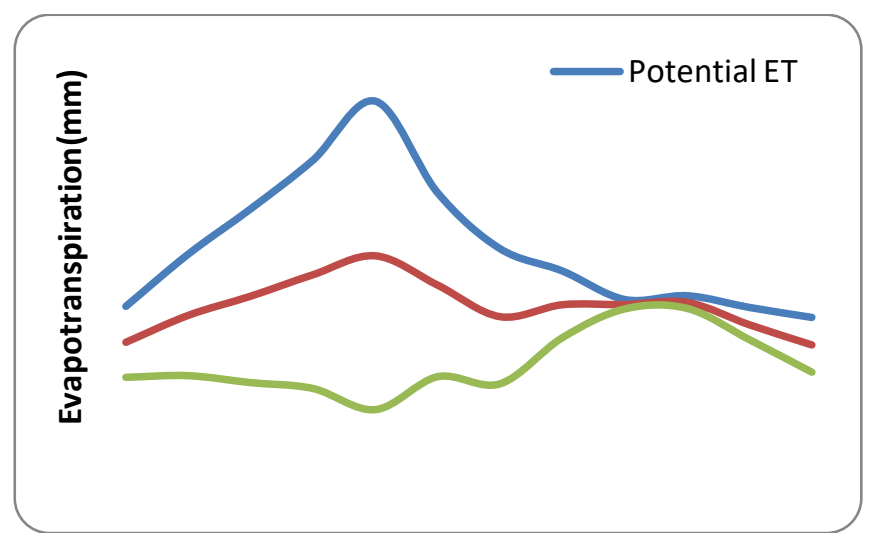

Fig 5: Mean monthly values of ETp, ETw and ETa for the Afzalpur station

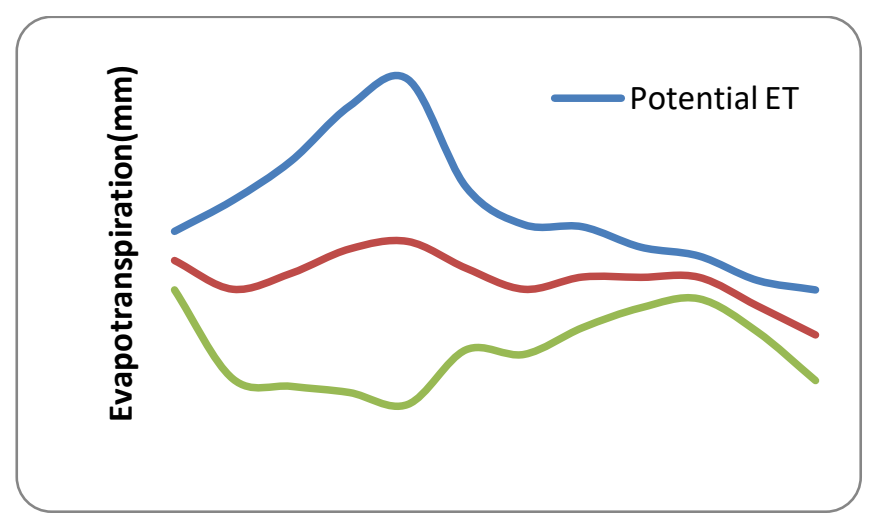

Fig 6: Mean monthly values of ETp, ETw and ETa for the Hungund station

Published By: Blue Eyes Intelligence Engineering \& Sciences Publication 
Standardized values were obtained by taking the ratio of monthly mean ETp, ETa and rainfall values with the corresponding monthly mean ETw values. Fig 7 and Fig 8 depict these plots for the Afzalpur and Hungund stations respectively.

From these graphs, it is clear that the trend line for the standardized ETp values decrease towards the standardized ETw values with the increase in standardized rainfall values. Similarly, with the increase in standardized rainfall values, standardized ETa values rise towards the standardized ETw. Since there is similarity between the CRAE hypothesis shown in Fig 1 with Fig 7 and Fig 8, it may be concluded that the hypothesis is valid at the Afzalpur and Hungund stations.

\section{$H$. Validation of the AA model estimates with the MODI6 ET}

Because ground-based data of measured ETa is rarely available, ETa estimates provided by the MODIS MOD16 ET product were used to validate the results of this study for the year 2006. MOD16ET is a global product of ETa values for the vegetated land mass available from 2000 to 2016 . In the present study, the eight-day composite ET product was downloaded and converted to an accessible form. Monthly mean ETa values were obtained for the year 2006 and compared with corresponding

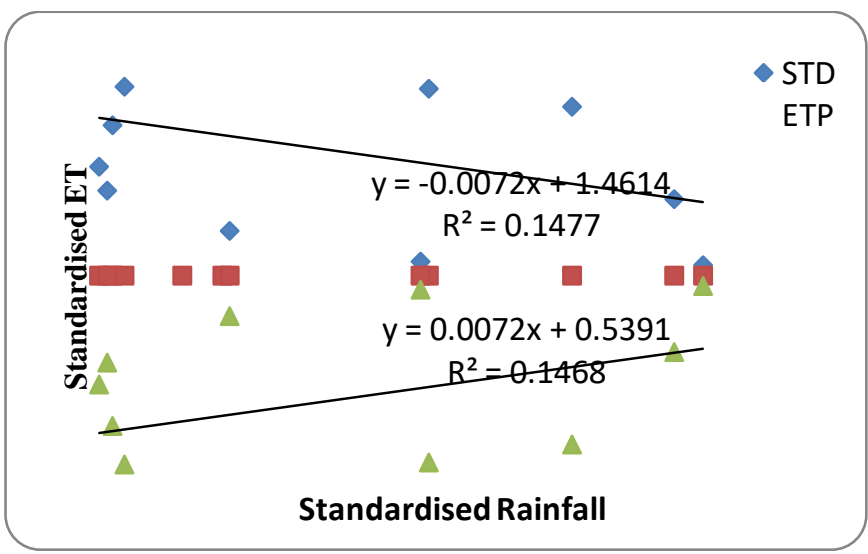

Fig 7: Variation of Standardized values of monthly mean ETp, ETw and ETawithstandardized rainfall for the Afzalpur station

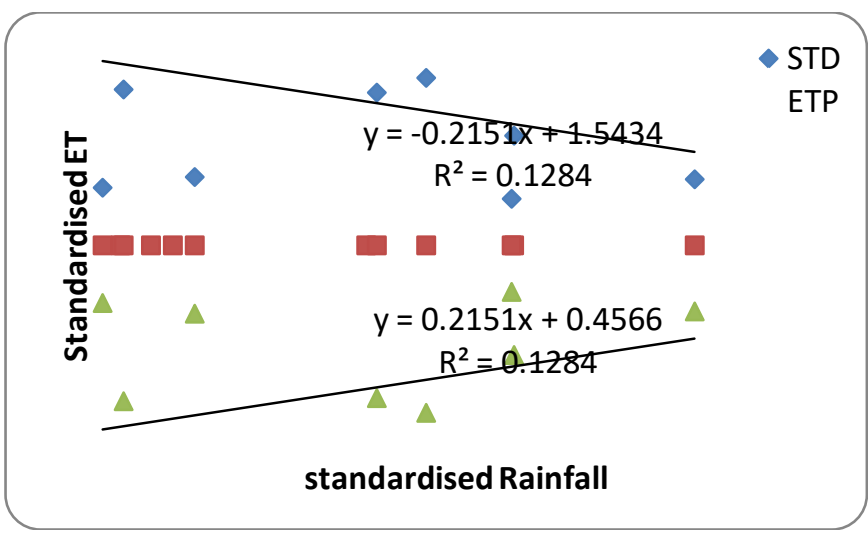

Fig 8: Variation of Standardized values of monthly mean ETp, ETw and ETa with standardized rainfall for the Hungund station

ETa values obtained with the AA model. Table 2 shows the values of ETa estimated using the AA model and the ETa values as obtained from theMOD16 product for both climate stations. Fig 9 and Fig 10 show these values as scatter plots for the Afzalpur and the Hungund stations respectively. The performance of the AA model relative to MOD16 was evaluated in terms of the slope of the trend line and also the value of coefficient of determination $\left(\mathrm{R}^{2}\right)$. For the perfect model, both slope and $\mathrm{R}^{2}$ should be equal to unity. From Fig. 9, it can be seen that at the Afzalpur station, the performance of the AA model is only moderately good since the slope of the trend line is 0.82 and $R^{2}$ is 0.694 . On the other hand, the AA model was significantly more accurate at the Hungund station as evident from slope of 1.33 and $\mathrm{R}^{2}$ of 0.916 . Root Mean Square Error (RMSE) calculated for the station Afzalpur and Hungund are 0.83 and $0.81 \mathrm{~mm}$ day $^{-1}$ respectively, which depicts that for the two stations AA model gives fairly satisfactory results of Evapotranspiration as compared with the MODIS evapotranspiration.

\section{CONCLUSIONS}

The AA model which is based on the Bouchet's (1963) [2] CR hypothesis was applied in the study area and ET values for monthly time steps were obtained. The results from the AA model showed that the application of Complementary Relationship hypothesis on the study area is reliable for the semi-arid regions like Afzalpur and Hungund for the monthly time steps.

Table II: Monthly mean ETa values obtained by the AA model and MOD16

\begin{tabular}{|c|c|c|c|c|}
\hline Station & \multicolumn{2}{|c|}{ Afzalpur } & \multicolumn{2}{c|}{ Hungund } \\
\hline Month & $\begin{array}{c}\text { AA } \\
\text { model } \\
\text { ET(mm) }\end{array}$ & $\begin{array}{c}\text { MODIS } \\
\text { ET(mm) }\end{array}$ & $\begin{array}{c}\text { AA } \\
\text { model } \\
\text { ET(mm) }\end{array}$ & $\begin{array}{c}\text { MODIS } \\
\text { ET } \\
(\mathrm{mm})\end{array}$ \\
\hline January & 1.59 & 1.47 & 1.62 & 1.09 \\
\hline February & 1.86 & 0.92 & 1.47 & 0.52 \\
\hline March & 1.59 & 0.69 & 1.83 & 1.12 \\
\hline April & 0.85 & 0.42 & 1.08 & 0.21 \\
\hline May & 0.99 & 0.5 & 1.16 & 0.21 \\
\hline June & 3.73 & 1.75 & 2.32 & 2.15 \\
\hline July & 1.34 & 1.64 & 2.5 & 1.62 \\
\hline August & 2.12 & 2.55 & 2.5 & 1.57 \\
\hline September & 3.98 & 2.9 & 2.87 & 2.99 \\
\hline October & 4.19 & 4.63 & 3.27 & 3.16 \\
\hline November & 3.68 & 2.94 & 2.94 & 2.37 \\
\hline December & 2.28 & 1.99 & 1.91 & 0.96 \\
\hline
\end{tabular}




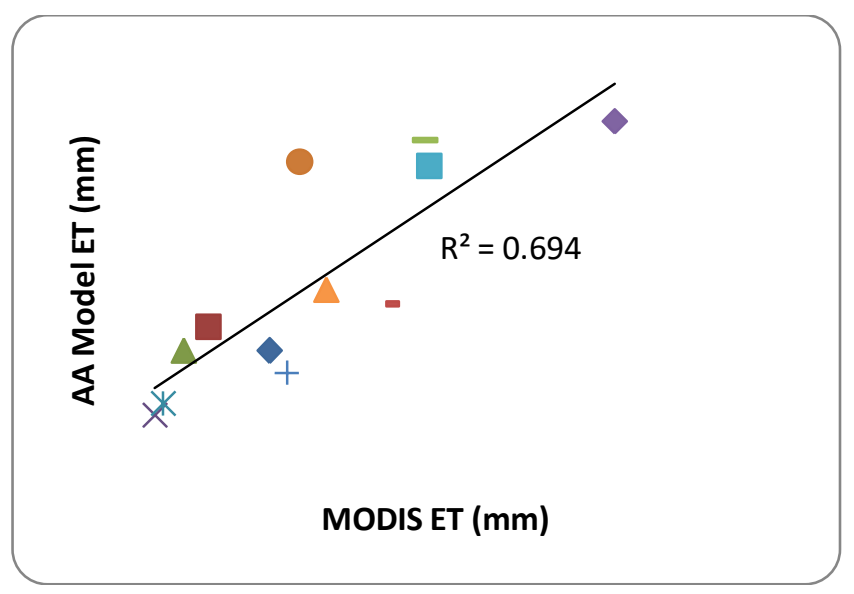

Fig 9: ETa estimated by AA model across the ET obtained by MOD16 product for Afzalpur Station.

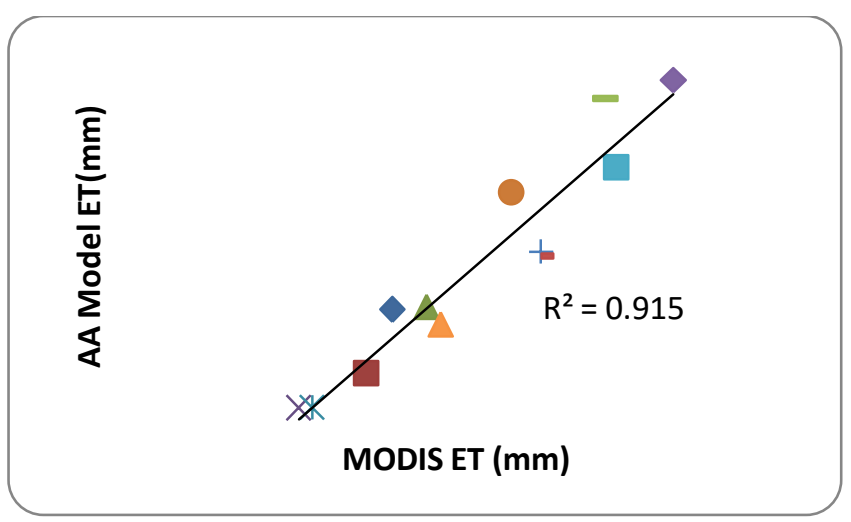

Fig 10: ETa estimated by AA model across the ET obtained by MOD16 product for Hungund Station

The obtained values of monthly ET from AA model are evaluated with the MODIS MOD16 ET product to find the accuracy of the AA model for the year 2006. The validation with the MODIS data proved that the ET values obtained by the AA model are reasonably in good agreement with the ET values of MODIS MOD16 ET product. Hence the AA model can be used to estimate actual ET in similar catchments with nearly same climatic properties.

However, there might be a necessity to calibrate the parameters that are applied to the AA model for the results to be more accurate. Using the region-specific factors like the extent of urbanization, changes in the rainfall over the years, etc., there might be an improvement in the evaluation of ET. Future scope of the project lies in improving the model with the locally available parameters so that the accuracy of the model could be improved for the extensive use of the model to a similar basin.

\section{REFERENCES}

1. R. G. Allen, P. L. S, D. Raes, and S. Martin, "Crop evapotranspiration: Guidelines for computing crop water requirements" FAO Irrig. Drain. Pap. 56, pp. 1-15, 1998.

2. R. J. Bouchet, "Évapotranspiration Réelle Et Potentielle Signification Climatique," Int. Assoc. Sci. Hydrol., vol. 62, pp. 134-162, 1963.

3. F. I. Morton, "Operational estimates of areal evapotranspiration and their significance to the science and practice of hydrology," J. Hydrol., vol. 66, no. 1-4, pp. 1-76, 1983.
4. W. Brutsaert and H. Stricker, "An Advection-Aridity Approach to Estimate Actual Regional Evapotranspiration," water Resour. Res., vol. 15, no. 2, 1979.

5. J. Szilagyi, M. T. Hobbins, and J. Jozsa, "Modified Advection-Aridity Model of Evapotranspiration," J. Hydrol. Eng., vol. 14, no. June, p. 569, 2009.

6. M. T. Hobbins, J. A. Ramirez, and C. Brown, "The complementary relationship in estimation of regional evapotranspiration: The Complementary Relationship Areal Evapotranspiration and Advection-Aridity models," vol. 37, no. 5, pp. 1367-1387, 2001.

7. M. B. Parlange and G. G. Katul, "An advection Aridity Evaporation model," water Resour. Res., vol. 28, no. 1, pp. 127-132, 1992

8. G. Yang, C. Zhao, and Q. Xu, "Spatial-temporal analysis of field evapotranspiration based on complementary relationship model and IKONOS data," Int. Geosci. Remote Sens. Symp., pp. 2836-2839, 2013.

9. C. Y. Xu and Chen. D, "Comparison of seven models for estimation of evapotranspiration and groundwater recharge using lysimeter measurement data in Germany," vol. 3734, no. September 2004, pp. 3717-3734, 2005.

10. C. $\mathrm{Xu}$ and V. P. Singh, "Evaluation of three complementary relationship evapotranspiration models by water balance approach to estimate actual regional evapotranspiration in different climatic regions," vol. 308 , pp. 105-121, 2005.

11. T. Nakamichi and T. Moroizumi, "Applicability of three complementary relationship models for estimating actual evapotranspiration in urban area," vol. 1, no. 1, pp. 117-123, 2015

12. S. A. Banimahd, D. Khalili, A. A. Kamgar-Haghighi, and S. Zand-Parsa, "Evapotranspiration model selection for estimation of actual evaporation from bare soil, as required in annual potential groundwater recharge studies of a semi-arid foothill region," Arch. Agron. Soil Sci., vol. 61, no. 10, pp. 1455-1472, 2015.

13. C. H. B. Priestley and R. J. T. A. Physics, "On the Assessment of Surface Heat Flux and Evaporation Using Large-Scale Parameters," no. February, pp. 81-92, 1972.

14. Nandagiri. L. Areal Evapotranspiration Estimation Using Several Alternative Formulations of the CRAE Hypothesis. Proceedings of the 27th IAHR Congress, San Fransisco,10-15 August 1997.

\section{AUTHORS PROFILE}

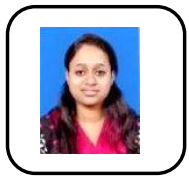

Ananya S G is a Master of Technology Student in the Department of Applied Mechanics and Hydraulics at the National Institute of Technology Karnataka, Surathkal. Her areas of interest are Evapotranspiration, Rainfall- Runoff relationships and Artificial Neural Network. 
Dr. Lakshman Nandagiri currently works as Professor in the Department of Applied Mechanics and Hydraulics at the National Institute of Technology Karnataka, Surathkal with 33 years of teaching experience. He did his $\mathrm{PhD}$ in 'Fields Soil Moisture Regimes and Hydrology of Irrigated Plots'. He has more than 30 publications in international journals and more than 45 research papers in conference proceedings. His research interests are Catchment/Watershed Hydrology, Vadose Zone process, Soil Moisture Measurement, Evapotranspiration, Irrigation scheduling, Remote Sensing/GIS applications in Hydrology, Multivariate Statistics and Artificial Neural Network applications. He is a member of International Association of Hydrological Sciences and a life member of Indian Society of Technical Education and Indian Society for Geomatics. One of his Research papers has been awarded Gold Medal for Best Paper in the National Seminar on Signals, Data \& System Modeling, Simulation \& Analysis, 1995, Bhatkal, India. And another research paper has won 'Best Paper in Conference Theme' in International Conference on 'Water, Environment, Energy and Society' (ICWEES 2016), held at Bhopal during March 15-19, 2016. 